\title{
A COMPARATIVE STUDY ON THE UTILIZATION OF SUMAC AND ROSEMARY AS ANTIMICROBIAL COMPONENT IN PRESERVATION OF KOFTA PRODUCT DURING FROZEN STORAGE
}

\author{
ABED- ELHAK, NASRA A., SAMIHA A. ALLOUSH and HALA M. ZAKI
}

Food Technology Research Institute, ARC, Giza.

(Manuscript received 12 July 2015)

\begin{abstract}
$\mathrm{S}$ pices (sumac and rosemary), are given more attention in natural antimicrobial researches. The present study was carried out to extend the shelf life of kofta (raw meat product with spices) under freezing conditions. The formulas contained individual concentration of sumac or rosemary $(0,1,1.5$ and $2 \%$ ) powders. The microbial load of the used commodities (raw minced meat and spices) were assessed before storage, while, kofta samples were evaluated for the zero time (after three hours) and after storing the samples for 3, 6,9 and 12 months. Kofta samples were fried and microbiologically estimated before and after frozen storage. Sensory charaterists before storage were also evaluated. The results showed that the highly acceptance treat meat was $2 \%$ sumac . The obtained results indicated that the total count of bacteria in sumac and rosemary was $2 \times 10$ and $5 \times 10 \mathrm{CFU} / \mathrm{g}$ sample, respectively, while the total count of molds and yeasts was $1 \times 10$ and $2 \times 10 \mathrm{CFU} / \mathrm{g}$ sample, respectively. Coliform group, Staphylococcus aureus and Salmonella spp were not detected in both spices. Increasing the percentage of added sumac or rosemary decreased all the tested microorganisms. Results showed that both sumac and rosemary spices can be considered as potential sources of fiber which is helpful in alleviating gastrointestinal disorders. After 12 months of storage, the counts of all the studied microorganisms (total counts, molds and yeasts, Salmonella spp and Staphylococcus aureus) of treated samples were appreciably decreased compared to those before storage. It could be concluded that the sumac is a good source of phenolic compounds and could be utilized as strong antioxidants.
\end{abstract}

Keywords: Antimicrobial activity, antioxidant activity , Rosemary , Sumac, microbiological analysis.

\section{INTRODUCTION}

Meat products, including kofta, contain mainly meat and some spices as major ingredients. It then follows the main mechanism of spoilage, microbial spoilage and fat deterioration which affects both the keeping and organoleptic quality of meat. In meat processing, reservoirs of microorganisms include meat components, seasoning formulating ingredients, meat handlers with poor personal hygiene, animal skin ,byproducts, slaughter and the environment (air and water for processing), transport 
and storage facilities (Mrema et al.,2006). Because of the high nutritive value of meat and meat products, fresh meat could only remain fresh for a short time before its spoilage, and to prevent this, meat should be processed into products. Meat seemed to be prone to both microbial and oxidative spoilage and, therefore, it would be desirable to use a preservative with both antioxidant and antimicrobial properties (Omojola, 2008).

Food antimicrobials are mostly synthetic chemicals and some are limited to use in foods, because they may cause adverse effects on public health and reluctance by consumers. Therefore, much attention in recent years has been focused on extracts from herbs and spices, which have been used for many centuries to improve the sensory characteristics and to extend the shelf life of foods. In the recent years, the attentions have been focused on using extracts from spices to improve sensory characteristics and extending the shelf life of food products. In addition, spices could be added to food, not only for flavors, but also for preservation. Rosemary is a powerful herb belonging to the Lamiaceae family that originates from the Mediterranean Region (Asia et al., 2013). Kossah et al., (2013) indicated that Syrian sumac fruit extracts might be used as a natural agent to prevent the growth of food spoilage bacteria, particularly, Helicobacter pylori leading to the reduction of gastroenteritis risk.

Sumac is documented to possess antibacterial, hepatoprotective, antifungal, antioxidant and anti-inflammatory Özcan and Haciseferogullari 2004) activities. Antioxidant properties of rosemary spice in foods have also been investigated (Musa, 2003). As the implementation of natural compounds in meat products is limited, in the present study, the possibility to prolong the shelf life of kofta as ground meat product was addressed. The investigation based on the use of natural spices, sumac and rosemary into the minced meat under cold storage conditions.

\section{MATERIALS AND METHODS}

\section{Plant materials and chemicals}

Spices including sumac (Rhus coriaria) and rosemary (Rosmarinus Officinalis L.) as well as onions, salt and sunflower oil were obtained from local market at Cairo and used for preparation of beef burger. Soy protein was purchased from the Food Technology Research Institute, Agricultural Research Center ,Giza, Egypt. Minced meat was purchased from butcher shop in local market at Giza. Soy protein was rehydrated (by mixing one part of powdered soy protein with two parts of tap water) 
before addition to meat. The 2,2-diphenyl-1-picrylhydrazyl (DPPH) Sigma (SigmaAldrich), was purchased from local company.

Nutrient agar, Malt agar, MAC-CONKEY agar, Mannitol Salt agar and Salmonella agar media used for estimating the microbial growth were obtained from Biolife Italian Company dealer at Cairo.

\section{Methods}

\section{Kofta samples preparation and storage}

Seven types of kofta with similar ingredients in type and quantity except the level of rosemary spice and sumac were prepared in Experimental Kitchen, Food Technology Research Institute, Agricultural Research Center. Tested samples were formulated to contain individual concentration of $0,1,1.5$ and $2 \%$ sumac or rosemary powders. The ingredient percentages of kofta formulations are shown in Table (1). Immediately after the addition of ingredients, meat samples and spices were thoroughly mixed using laboratory mixer. After preparation of each formula, the samples were packed in polyethylene bags and were stored in the refrigerator for 12 months at- $4^{\circ} \mathrm{C}$ until required. Every3 month, the samples were subjected for microbiological analysis.

Table 1. Ingredient percentages of kofta formulations ( $\mathrm{g} / 100 \mathrm{~g})$.

\begin{tabular}{|l|c|c|c|c|c|c|c|}
\hline Kofta sample & Meat & Sumac & Rosemary & $\begin{array}{c}\text { Soy } \\
\text { protein }\end{array}$ & Onion & Salt & $\begin{array}{c}\text { Black } \\
\text { pepper }\end{array}$ \\
\hline Control & 73.5 & - & - & 5 & 20 & 1.0 & 0.5 \\
\hline$(1 \%)$ Sumac & 72.5 & 1.0 & - & 5 & 20 & 1.0 & 0.5 \\
\hline$(1.5 \%)$ Sumac & 72.0 & 1.5 & - & 5 & 20 & 1.0 & 0.5 \\
\hline$(2 \%)$ Sumac & 71.5 & 2.0 & - & 5 & 20 & 1.0 & 0.5 \\
\hline$(1 \%)$ Rosemary & 72.5 & - & 1.0 & 5 & 20 & 1.0 & 0.5 \\
\hline$(1.5 \%)$ Rosemary & 72.0 & - & 1.5 & 5 & 20 & 1.0 & 0.5 \\
\hline$(2.5 \%)$ Rosemary & 71.5 & - & 2.0 & 5 & 20 & 1.0 & 0.5 \\
\hline
\end{tabular}

\section{Chemical composition:-}

Moisture, ether extract, crude fiber, protein and ash of the samples(sumac and rosemary), were measured according to AOAC (2000).

\section{DPPH radical-scavenging activity:}

The DPPH free radical scavenging activity was determined by the method of Yang et al., (2008) with some modifications. sample, at different concentrations in ethanol ( $2 \mathrm{ml}$ ), was mixed with $2 \mathrm{ml}$ of ethanolic solution containing $1 \mathrm{mM} \mathrm{DPPH}$. The mixture was shaken vigorously shaken, then left to stand for $30 \mathrm{~min}$ in the dark. The absorbance was measured at $517 \mathrm{~nm}$. The absorbance of the control was obtained by 
replacing the sample with ethanol. The DPPH scavenging activity was calculated as follows:

DPPH radical scavenging activity (\%) $=\left[\begin{array}{lll}1 & - \text { absorbance of }\end{array}\right.$ sample/absorbance of control] X 100

\section{Determination of total phenolic content:}

The total phenolic content was estimated by Folin-Ciocalteu colorimetric method, based on the procedure in Singleton and Rossi (1965). Procedure: Briefly, the crude extract $(50 \mathrm{mg})$ was mixed with Folin-Ciocalteu reagent $(0.5 \mathrm{~mL})$ and deionized water $(7.5 \mathrm{~mL})$. The mixture was kept at room temperature for $5 \mathrm{~min}$, and then, $10 \mathrm{~mL}$ of $7 \%$ sodium carbonate was added to the mixture, and then incubated for $90 \mathrm{~min}$ at room temperature. After incubation the absorbance against the reagent blank was determined at $760 \mathrm{~nm}$. The total phenolic content of the plant was expressed as gram of tannic acid equivalent (TAE) per $100 \mathrm{~g}$ extract.

\section{Cooking treatments}

For frying, kofta samples were shallow fried in sunflower oil until it becomes golden .

\section{Sensory evaluation:-}

The Sensory characteristics of the cooked kofta were carried out by ten well trained ten panelists of Food Technology Research Institute (FTRI) who were asked to evaluate the tested samples for color, taste, odor, texture, appearance and tenderness attributes, according to the method described by A.M.S.A.(1995).

\section{Microbiological evaluation of samples}

The microbiological evaluation of kofta samples includes; the determination of total plate count and the detection of coliform group, Staphylococcus aureu, Salmonella spp and yeasts and molds.

\section{Sample preparation}

Five $\mathrm{g}$ of each of the tested samples were weighted under aseptic conditions and transferred into a sterile flask. A known volume of sterile water $(45 \mathrm{ml})$ was added and shacked for 2-3 $\mathrm{min}$, then different dilutions were made $\left(1 / 10,1 / 10^{2}\right.$ $, 1 / 10^{3,} 1 / 10^{4}, 1 / 10^{5}$ and $1 / 10^{6}$ ).

\section{Microbiological analysis}

\section{Total plate count}

Total plate count was assessed on nutrient agar medium. Plates were incubated at $37^{\circ} \mathrm{C}$ for 48 hours (A.P.H.A., 2004). 


\section{Staphylococcus aureus}

Staphylococcus aureus were determined on Mannitol Salt agar medium, plates were incubated at $37^{\circ} \mathrm{C}$ for 48 hours according to (Difco, 1994).

\section{Coliform group}

Coliform group was determined on MAC-CONKEY agar. Plates were incubated at $37^{\circ} \mathrm{C}$ for $48 \mathrm{~h}$. according to the method of A.P.H.A., (2004).

\section{Salmonella spp}

Salmonella spp were detected using Difco Salmonella Shiguella agar medium. The plates were incubated at $37^{\circ} \mathrm{C}$ for 48 hours (Difco,1994) .

\section{Molds and yeasts}

Molds and yeasts counts were assessed on malt agar medium. Plates were inoculated at $30^{\circ} \mathrm{C}$ for $72 \mathrm{~h}$. as mentioned by A.P.H.A. (2004).

Statistical analysis: Results were subjected to the analysis of variance (ANOVA) using the SAS (1987) for Windows, and Duncan's multiple-range test was used to compare means at a significance level of $5 \%$.

\section{RESULTS AND DISCUSSION}

Chemical composition: The chemical compositions of sumac and rosemary were presented in Table (2). It was found that sumac possessed higher contents in ether extract and crude fiber than rosemary. But, higher values of protein and ash were realized by rosemary as compared with sumac. These results are agreed with Özcan and Haciseferogullari (2004). Results showed that sumac species can be considered as potential sources of dietary fiber which is helpful in alleviating gastrointestinal disorders. Results in the same Table showed that moisture ,ether extract, protein, crude fiber and ash content of rosemary were 8.53, $5.84,4.48,13.2$ and 8.03\%, respectively. Farrell (1999) found that rosemary contained $9.3 \%$ moisture, $15.2 \%$ ether extract, $4.9 \%$ protein and $6.5 \%$ ash.

The same Table, showed that sumac contains a high amount of phenolic and scavenging activity of DPPH (136.6 sumac and 43.41, respectively) than that of rosemary. The relationships between total phenolic content and antioxidant properties of many plants have been investigated in previous studies. Some studies obtained good positive linear correlations; others obtained poor linear correlations or even could not explain the relationship between total antioxidant activity and phenolic content, as presented by Mata (2007).The addition of rosemary extract before cooking lowered oxidative changes during cooking and later during storage. This study is in agreement with Rhee (1988) who reported that the rosemary extracts containing 
phenolic derivatives to have strong antioxidant effects on cooked meat, findings where it was found that lipid oxidation is greatly affected by storage time and elevated temperature. Recently, the fruits of $R$. coriaria growing in Syria were found to contain a high amount of phenolic compound (Kossah et al., 2013).

Table 2. Chemical composition (\%on dray weight basis). Total phenolic as (g TAE/ $100 \mathrm{~g}$ ) and DPPH radical-scavenging activity of sumac and rosemary \%

\begin{tabular}{|c|c|c|}
\hline Items & Sumac & Rosemary \\
\hline Moisture & 11.60 & 8.53 \\
\hline protein & 2.60 & 4.48 \\
\hline Ash & 1.80 & 8.03 \\
\hline Ether extract & 7.40 & 5.84 \\
\hline Crude fiber & 22.6 & 13.2 \\
\hline Phenolic content \\
(g 100 g extract $)$
\end{tabular}

\section{Microbiological evaluation of sumac, rosmary and raw minced meat}

Numbers of recovered microorganisms are illustrated in Table (3). The obtained results indicated that the total count of bacteria in sumac and rosemary was $2 \times 10$ and5x10 CFU/g respectively, while the total count of molds and yeasts was $1 \times 10$ and $2 \times 10 \mathrm{CFU} / \mathrm{g}$, respectively.

Table 3. Microbiological quality of raw material

\begin{tabular}{|c|c|c|c|}
\hline \multirow{2}{*}{ Microorganisms } & \multicolumn{3}{|c|}{ Microbial count (CFU/g) } \\
\hline \multirow{2}{*}{ Total counts } & Meat minced & sumac & Rosemary \\
\cline { 2 - 4 } & $6 \times 10^{6}$ & $2 \times 10$ & $5 \times 10$ \\
\hline Molds and yeasts & $4 \times 10^{5}$ & $1 \times 10$ & $2 \times 10$ \\
\hline E. Coli & ND & ND & ND \\
\hline Staph. aureus & $9 \times 10$ & ND & ND \\
\hline Salmonella spp & 28 & ND & ND \\
\hline
\end{tabular}

N.D.: not detected 
Coliform group, Staphylococcus aureus and Salmonella spp. were not detected in both spices. It could be also observed that the total bacterial counts in raw meat reached $6 \times 10^{6} \mathrm{CFU} / \mathrm{g}$ sample while the molds and yeasts count were $4 \times 10^{5} \mathrm{CFU} / \mathrm{g}$ sample. Data in the same Table showed that Salmonella spp and Staph. aureus were detected in the tested raw meat sample. The obtained results are in the same line with those of Mrema et al., (2006) who found some kinds of Salmonella in raw meat samples. Meat shelf-life would depend on many factors including the number and types of microorganisms initially present and their subsequent growth, in addition, among other issues; the storage temperatures could play an important role in the handling of the raw meat products (Nychas et al., 2008).

\section{Sensory evaluation}

Sensory evaluations are the most significant methods for predicting consumer acceptability (Rajalakshmi and Narasimhan 1996).

Table 4. Sensory properties of kofta samples

\begin{tabular}{|l|c|c|c|c|c|c|}
\hline \multirow{2}{*}{ Sample } & \multicolumn{7}{|c|}{ Sensory characteristics of the fried kofta } \\
\cline { 2 - 7 } & $\begin{array}{c}\text { Color } \\
(10)\end{array}$ & $\begin{array}{c}\text { Taste } \\
(10)\end{array}$ & $\begin{array}{c}\text { Odor } \\
(10)\end{array}$ & $\begin{array}{c}\text { Texture } \\
(10)\end{array}$ & $\begin{array}{c}\text { Appearance } \\
(10)\end{array}$ & $\begin{array}{c}\text { Tenderness } \\
(10)\end{array}$ \\
\hline Control & $8.4^{\mathrm{d}}$ & $6.6^{\mathrm{d}}$ & $7.6^{\mathrm{e}}$ & $8.0^{\mathrm{d}}$ & $8.4^{\mathrm{d}}$ & $8.2^{\mathrm{d}}$ \\
\hline$(1 \%)$ Sumac & $9.1^{\mathrm{c}}$ & $8.5^{\mathrm{c}}$ & $8.5^{\mathrm{b}}$ & $8.3^{\mathrm{cd}}$ & $8.8^{\mathrm{b}}$ & $8.6^{\mathrm{b}}$ \\
\hline$(1.5 \%)$ Sumac & $9.2^{\mathrm{b}}$ & $8.7^{\mathrm{b}}$ & $8.7^{\mathrm{ab}}$ & $8.5^{\mathrm{b}}$ & $8.9^{\mathrm{ab}}$ & $8.6^{\mathrm{b}}$ \\
\hline$(2 \%)$ Sumac & $9.5^{\mathrm{a}}$ & $8.9^{\mathrm{a}}$ & $8.8^{\mathrm{a}}$ & $8.7^{\mathrm{ab}}$ & $9.0^{\mathrm{a}}$ & $8.5^{\mathrm{c}}$ \\
\hline$(1 \%)$ Rosemary & $8.2^{\mathrm{e}}$ & $8.5^{\mathrm{c}}$ & $8.0^{\mathrm{d}}$ & $8.3^{\mathrm{cd}}$ & $8.5^{\mathrm{c}}$ & $8.8^{\mathrm{ab}}$ \\
\hline$(1.5 \%)$ Rosemary & $8.2^{\mathrm{e}}$ & $8.85^{\mathrm{ab}}$ & $8.1^{\mathrm{cd}}$ & $8.4^{\mathrm{c}}$ & $8.7^{\mathrm{bc}}$ & $8.9^{\mathrm{a}}$ \\
\hline$(2.5 \%)$ Rosemary & $8.1^{\mathrm{f}}$ & $8.87^{\mathrm{a}}$ & $8.2^{\mathrm{c}}$ & $8.8^{\mathrm{a}}$ & $8.9^{\mathrm{ab}}$ & $8.9^{\mathrm{a}}$ \\
\hline
\end{tabular}

Results of the sensory evaluation are tabulated in Tables (4) and are represented the average score of the sensory properties and their statistically analyzed. Data indicated that regardless the slight variations among some sensory scores of the samples, significant differences were noticed for their sensory attributes (tenderness, texture and appearance) among cooked kofta samples. On the other hand, the control formula had the lowest score of odor and taste, but were significantly differed among the other tested samples. The results also showed that there were significant differences among kofta supplemented with sumac for color characteristics compared to other blends (control and kofta supplemented with rosemary). Sensory evaluations of cooked kofta with rosemary were significantly different in scores of color, odor, appearance and texture. The results were in agreement with those reported by Güntersperger et al., (1998). Rosemary spice is organoleptically acceptable at levels of $0.1-0.4 \%$ as reported by Oiye and Muroki (2002). 
It is worthy to mention that adding sumac and rosemary to kofta samples extended shelf life of the stored kofta at $4^{\circ} \mathrm{C}$ up to 12 months. The counts of total counts, molds and yeasts, E. coli, Salmonella spp and Staphylococcus aureus in kofta samples were periodically determined( every three months ) throughout storage period to follow up changes in the number of the detected microorganisms (Tables 5, $6,7,8$ and 9). Results in Table (5) showed that total bacterial count of uncooked samples at zero time (after $3 \mathrm{hr}$ form samples preparing) ranged from $3 \times 10^{5}$ in rosemary $(1.5 \%)$ to $3 \times 10^{6}$ in control sample. The same Table indicated that Salmonella spp count ( $\mathrm{cfu} / \mathrm{g}$ ) in uncooked samples at zero time storage ranged from $28 \mathrm{cfu} / \mathrm{g}$ in control sample to $10 \mathrm{cfu} / \mathrm{g}$ in sumac (2\%) sample. Table (5) illustrated that the molds and yeasts of uncooked at zero time storage ranged from $7 \times 10^{5} \mathrm{cfu} / \mathrm{g}$ in control to $3 \times 10^{4} \mathrm{cfu} / \mathrm{g}$ in sumac $2 \%$. Data in Table (5) also illustrated the effect of cooking methods on microbiological quality of freshly prepared kofta at zero time. It could be noticed that the applied cooking methods (frying) greatly decreased the number of recovered microorganisms of TC and molds and yeasts in the cooked kofta. However, it totally destroyed Salmonella serotypes. These findings are in accordance with those of other studies, which noted the absence of Salmonella growth at refrigeration temperatures $\left(7\right.$ to $\left.^{\circ} \mathrm{C}\right)$ in beef (Mattick et al., 2003).

Table 5. Microbiological count of raw and cooked kofta after storage and at zero time

\begin{tabular}{|l|c|c|c|c|c|}
\hline \multirow{2}{*}{ Sample } & \multicolumn{4}{|c|}{ Count in uncooked samples } & \\
\cline { 2 - 6 } & $\begin{array}{c}\text { Total } \\
\text { bacterial } \\
\text { counts } \\
\text { (cells/g } \\
\text { sample) }\end{array}$ & $\begin{array}{c}\text { Yeasts and } \\
\text { moulds } \\
\text { (colons/g } \\
\text { sample) }\end{array}$ & $\begin{array}{c}\text { Coliform } \\
\text { group }\end{array}$ & Staph. aureus & Salmonella spp \\
\hline \multicolumn{1}{|c|}{ Control } & $3 \times 10^{6}$ & $7 \times 10^{5}$ & ND & $9.0 \times 10$ & 28 \\
\hline$(1 \%)$ Sumac & $4 \times 10^{5}$ & $8 \times 10^{4}$ & ND & $7.5 \times 10$ & 14 \\
\hline$(1.5 \%)$ Sumac & $6 \times 10^{4}$ & $6 \times 10^{4}$ & ND & $6.5 \times 10$ & 12 \\
\hline$(2 \%)$ Sumac & $5 \times 10^{4}$ & $3 \times 10^{4}$ & ND & $6.0 \times 10$ & 10 \\
\hline$(1 \%)$ Rosemary & $4 \times 10^{5}$ & $2.1 \times 10^{4}$ & ND & $8.0 \times 10$ & 18 \\
\hline$(1.5 \%)$ Rosemary & $3 \times 10^{5}$ & $1.8 \times 10^{4}$ & ND & $7.5 \times 10$ & 15 \\
\hline$(2.5 \%)$ Rosemary & $1.8 \times 10^{5}$ & $9 \times 10^{3}$ & ND & $7.0 \times 10$ & 12 \\
\hline \multicolumn{7}{|c|}{ Count in fried samples } & \\
\hline Control & $4 \times 10^{4}$ & $8 \times 10^{3}$ & ND & ND & ND \\
\hline$(1 \%)$ Sumac & $7 \times 10^{3}$ & $6 \times 10^{3}$ & ND & ND & ND \\
\hline$(1.5 \%)$ Sumac & $9 \times 10^{3}$ & $5 \times 10^{3}$ & ND & ND & ND \\
\hline$(2 \%)$ Sumac & $6 \times 10^{3}$ & $2 \times 10^{3}$ & ND & ND & ND \\
\hline$(1 \%)$ Rosemary & $9 \times 10^{4}$ & $9 \times 10^{3}$ & ND & ND & ND \\
\hline$(1.5 \%)$ Rosemary & $7 \times 10^{4}$ & $6 \times 10^{3}$ & ND & ND & ND \\
\hline$(2.5 \%)$ Rosemary & $4 \times 10^{4}$ & $4 \times 10^{3}$ & ND & ND & ND \\
\hline
\end{tabular}


Kossah et al., (2013) indicated that Syrian sumac fruit extract might be used as a natural agent to prevent the growth of food spoilage bacteria, particularly. pylori leading to the reduction of gastroenteritis risk. The highest concentration of sumac $2 \%$ showed the greatest decreasing effect of such counts among those treated concentrations. Following it, $2 \%$ rosemary came. The presence of microbial load to frying kofta might be due to increasing water and fat binding properties of meat products (Cofrades et al., 2000).

Data in Table (6) showed a similar effect on decreasing microbial counts in samples stored for three months. Data also showed that all the detected microorganisms counts in the stored samples for zero time were greatly lower than those of corresponding samples either before or after storage for three months.

Table 6. Microbiological counts of raw and cooked kofta after storage for three months

\begin{tabular}{|c|c|c|c|c|c|}
\hline \multirow[b]{2}{*}{ Sample } & \multicolumn{5}{|c|}{ Count in uncooked samples } \\
\hline & $\begin{array}{c}\text { Total } \\
\text { bacterial } \\
\text { counts } \\
\text { (cells/g } \\
\text { sample) }\end{array}$ & $\begin{array}{c}\text { Yeasts and } \\
\text { moulds } \\
\text { (colons/g } \\
\text { sample) }\end{array}$ & $\begin{array}{c}\text { Coliform } \\
\text { group }\end{array}$ & Staph. aureus & Salmonella spp \\
\hline Control & $3 \times 10^{6}$ & $7 \times 10^{4}$ & ND & $8.0 \times 10$ & ND \\
\hline (1\%) Sumac & $4 \times 10^{4}$ & $8 \times 10^{3}$ & ND & $6.5 \times 10$ & ND \\
\hline$(1.5 \%)$ Sumac & $6 \times 10^{3}$ & $6 \times 10^{3}$ & ND & $5.5 \times 10$ & ND \\
\hline (2\%) Sumac & $4 \times 10^{3}$ & $3 \times 10^{3}$ & ND & $5.0 \times 10$ & ND \\
\hline (1\%) Rosemary & $9 \times 10^{3}$ & $1.1 \times 10^{4}$ & ND & $7.0 \times 10$ & ND \\
\hline (1.5\%) Rosemary & $6 \times 10^{3}$ & $9 \times 10^{3}$ & ND & $6.5 \times 10$ & ND \\
\hline (2.5\%) Rosemary & $2 \times 10^{3}$ & $6 \times 10^{3}$ & ND & $6.0 \times 10$ & ND \\
\hline \multicolumn{6}{|c|}{ Count in fried samples } \\
\hline Control & $4 \times 10^{3}$ & $6 \times 10^{3}$ & ND & ND & ND \\
\hline (1\%) Sumac & $9 \times 10^{2}$ & $9 \times 10^{2}$ & ND & ND & ND \\
\hline$(1.5 \%)$ Sumac & $8 \times 10^{2}$ & $5 \times 10^{2}$ & ND & ND & ND \\
\hline (2\%) Sumac & $6 \times 10^{2}$ & $2 \times 10^{2}$ & ND & ND & ND \\
\hline (1\%) Rosemary & $8 \times 10^{2}$ & $8 \times 10^{2}$ & ND & ND & ND \\
\hline (1.5\%) Rosemary & $6 \times 10^{2}$ & $6 \times 10^{2}$ & ND & ND & ND \\
\hline$(2.5 \%)$ Rosemary & $4 \times 10^{2}$ & $3 \times 10^{2}$ & ND & ND & ND \\
\hline
\end{tabular}

As shelf life of meat has always been a concern, refrigeration considered to be the most common method of extending the shelf life of meat. It could be noticed that the applied cooking methods (frying) greatly decreased the number of recovered microorganisms of TC and molds and yeasts in the cooked kofta.

However, it totally destroyed Salmonella serotypes and Staphylococcus aureus. The obtained results are in the line with those Mattick et al., (2003) who detected that Salmonella was found in $7.5 \%$ of frozen and $9.1 \%$ of the chilled sausages. It was also added that after cooking (frying), Salmonella cells was allowed 
to survive and the temperature profiles during cooking indicated that the lethal range was sometimes not reached. Whyte et al., (2003) noticed that the presence of pathogens, mostly gram negative enteric pathogens, such as Escherichia coli 0157:H7 and Salmonella serotypes. might be reduced by the application of steam to meat surfaces.

Table 7. Microbiological counts of raw and cooked kofta after storage for six months

\begin{tabular}{|c|c|c|c|c|c|}
\hline \multirow[b]{2}{*}{ Sample } & \multicolumn{5}{|c|}{ Count in uncooked samples } \\
\hline & $\begin{array}{c}\text { Total } \\
\text { bacterial } \\
\text { counts } \\
\text { (cells/g } \\
\text { sample) }\end{array}$ & $\begin{array}{l}\text { Yeasts and } \\
\text { moulds } \\
\text { (colons/g } \\
\text { sample) }\end{array}$ & $\begin{array}{c}\text { Coliform } \\
\text { group }\end{array}$ & Staph. aureus & Salmonella spp \\
\hline Control & $3 \times 10^{6}$ & $7 \times 10^{4}$ & ND & $7.0 \times 10$ & ND \\
\hline (1\%) Sumac & $9 \times 10^{3}$ & $10 \times 10^{2}$ & ND & $5.0 \times 10$ & ND \\
\hline (1.5\%) Sumac & $6 \times 10^{3}$ & $8 \times 10^{2}$ & ND & $4.5 \times 10$ & ND \\
\hline (2\%) Sumac & $1 \times 10^{3}$ & $5 \times 10^{2}$ & ND & $4.0 \times 10$ & ND \\
\hline (1\%) Rosemary & $6 \times 10^{3}$ & $9 \times 10^{2}$ & ND & $6.0 \times 10$ & ND \\
\hline$(1.5 \%)$ Rosemary & $3 \times 10^{3}$ & $6 \times 10^{2}$ & ND & $5.5 \times 10$ & ND \\
\hline (2.5\%) Rosemary & $1 \mathrm{X} 10^{3}$ & $4 \times 10^{2}$ & ND & $5.0 \times 10$ & ND \\
\hline \multicolumn{6}{|c|}{ Count in fried samples } \\
\hline Control & $4 \times 10^{3}$ & $6 \times 10^{2}$ & ND & ND & ND \\
\hline (1\%) Sumac & $9 \times 10^{2}$ & $5 \times 10^{2}$ & ND & ND & ND \\
\hline (1.5\%) Sumac & $8 \times 10^{2}$ & $3 \times 10^{2}$ & ND & ND & ND \\
\hline (2\%) Sumac & $6 \times 10^{2}$ & $2 \times 10^{2}$ & ND & ND & ND \\
\hline (1\%) Rosemary & $8 \times 10^{2}$ & $5 \times 10^{2}$ & ND & ND & ND \\
\hline (1.5\%) Rosemary & $6 \times 10^{2}$ & $3 \times 10^{2}$ & ND & ND & ND \\
\hline (2.5\%) Rosemary & $4 \times 10^{2}$ & $1 \times 10^{2}$ & ND & ND & ND \\
\hline
\end{tabular}

Data in Table (7) showed a similar effect in decreasing microbial counts of samples stored for six months. It also showed that all the detected microorganisms counts in the stored samples for six month were greatly lower than those of corresponding samples either before or after frying method storage for three month only.

The highest concentration (2\%) of either sumac or rosemary resulted in a greatest decreasing effect on such counts in samples stored for six month among those noticed for other concentrations. The effect of sumac and rosemary were gradually increased with increasing its added percentages. After six month of storage, 
values of the total counts, molds and yeasts and Staphylococcus aureus in samples with sumac or rosemary were appreciable lower than the control sample.

The tested samples before and after cooking at nine month storage were subjected to the total bacterial (TBC),yeast and mold, Salmonella, Staph. aureu and coliform group counts and the obtained results are shown in Table (8). The data revealed that the total bacterial count (TBC in kofta supplemented by sumac and rosemary ) after frying can be arranged in the following descending order kofta prepared with $2 \%$ sumac powder $\left(1 \times 10^{2}\right), 2 \%$, rosemary $\left(2 \times 10^{2}\right), 1.5 \%$ rosemary $\left(3 \times 10^{2}\right), 1.5 \%$ sumac $\left(3 \times 10^{2}\right), 1 \%$ rosemary $\left(5 \times 10^{2}\right)$, control $\left(5 \times 10^{5}\right)$. Extending storage time to nine months at $-4^{-} \mathrm{C}$ was accompanied by a decrease in yeast and mold. Results in the same Table showed that frying method of prepared samples eliminated Staph.aureus in all formulae.

Table 8. Microbiological counts of raw and cooked kofta after storage for nine months

\begin{tabular}{|c|c|c|c|c|c|}
\hline \multirow[b]{2}{*}{ Sample } & \multicolumn{5}{|c|}{ Count in uncooked samples } \\
\hline & $\begin{array}{c}\text { Total } \\
\text { bacterial } \\
\text { counts } \\
\text { (cells/g } \\
\text { sample) }\end{array}$ & $\begin{array}{c}\text { Yeasts and } \\
\text { moulds } \\
\text { (colons/g } \\
\text { sample) }\end{array}$ & $\begin{array}{l}\text { Coliform } \\
\text { group }\end{array}$ & Staph. aureus & Salmonella spp \\
\hline Control & $3 \times 10^{6}$ & $7 \times 10^{4}$ & ND & $6.0 \times 10$ & ND \\
\hline (1\%) Sumac & $9 \times 10^{2}$ & $7 \times 10^{2}$ & ND & $4.0 \times 10$ & ND \\
\hline$(1.5 \%)$ Sumac & $7 \times 10^{2}$ & $5 \times 10^{2}$ & ND & $3.5 \times 10$ & ND \\
\hline (2\%) Sumac & $5 \times 10^{2}$ & $3 \times 10^{2}$ & ND & $3.0 \times 10$ & ND \\
\hline (1\%) Rosemary & $6 \times 10^{2}$ & $4 \times 10^{2}$ & ND & $5.0 \times 10$ & ND \\
\hline$(1.5 \%)$ Rosemary & $3 \times 10^{2}$ & $3 \times 10^{2}$ & ND & $4.5 \times 10$ & ND \\
\hline (2.5\%) Rosemary & $2 \times 10^{2}$ & $2.7 \times 10^{2}$ & ND & $4.0 \times 10$ & ND \\
\hline \multicolumn{6}{|c|}{ Count in fried samples } \\
\hline Control & $5 \times 10^{5}$ & $5 \times 10^{2}$ & ND & ND & ND \\
\hline (1\%) Sumac & $7 \times 10^{2}$ & $1.2 \times 10^{2}$ & ND & ND & ND \\
\hline (1.5\%) Sumac & $3 \times 10^{2}$ & $9 \times 10$ & ND & ND & ND \\
\hline (2\%) Sumac & $1 \times 10^{2}$ & $8 \times 10$ & ND & ND & ND \\
\hline (1\%) Rosemary & $5 \times 10^{2}$ & $9 \times 10$ & ND & ND & ND \\
\hline (1.5\%) Rosemary & $3 \times 10^{2}$ & $7 \times 10$ & ND & ND & ND \\
\hline (2.5\%) Rosemary & $1 \times 10^{2}$ & $4 \times 10$ & ND & ND & ND \\
\hline
\end{tabular}

Results presented in Table (9) showed that addition of sumac or rosemary partially decreased the initial microbial count and slowed down the growth during the storage period in parallel to increasing the concentration. In general, the microbiological quality of meat products as purchased by the consumer relies on a number of factors, such as the quality of the raw materials, other ingredients or processing operations to the products as extraneous contaminants, sanitation during processing and packaging. At concentration of $1,1.5$ and $2 \%$, sumac or rosemary the mean aerobic counts in the samples were reduced. 
Control sample showed slightly higher counts of all the tested microorganisms after extending storage time up to 12 months than those of other samples treated with sumac and rosemary. These findings are concurrent and confirmed with that found by Kossah et al., (2013) who reported that the extract of Syrian sumac fruit can be used as a natural source of antimicrobial and antioxidant agents to preserve foodstuffs against a range of food related microorganisms. Sumac is rich in watersoluble tannins, and the antimicrobial activity of tannins is well documented (Chung et al.,1998). Addition of rosemary extract prior to cooking (on heat sterilized ground pork) lowered oxidative changes during precooking and storage (Güntersperger et al., 1998). The aforementioned results were agreed with Egyptian Organization for Standardization and Quality.

Table 9. Microbiological counts of raw and cooked kofta after storage for 12 months

\begin{tabular}{|c|c|c|c|c|c|}
\hline \multirow[b]{2}{*}{ Sample } & \multicolumn{5}{|c|}{ Count in uncooked samples } \\
\hline & $\begin{array}{c}\text { Total } \\
\text { bacterial } \\
\text { counts } \\
\text { (cells/g } \\
\text { sample) }\end{array}$ & $\begin{array}{l}\text { Yeasts and } \\
\text { moulds } \\
\text { (colons/g } \\
\text { sample) }\end{array}$ & $\begin{array}{c}\text { Coliform } \\
\text { group }\end{array}$ & $\begin{array}{l}\text { Staph. } \\
\text { aureus }\end{array}$ & $\begin{array}{c}\text { Salmonella } \\
\text { spp }\end{array}$ \\
\hline Control & $3 \times 10^{4}$ & $7 \times 10^{4}$ & ND & $5.0 \times 10$ & ND \\
\hline (1\%) Sumac & $7 \times 10^{2}$ & $7 \times 10$ & ND & $3.0 \times 10$ & ND \\
\hline (1.5\%) Sumac & $5 \times 10^{2}$ & $5 \times 10$ & ND & $2.5 \times 10$ & ND \\
\hline (2\%) Sumac & $2 \times 10^{2}$ & $3 \times 10$ & ND & $1.0 \times 10$ & ND \\
\hline (1\%) Rosemary & $4 \times 10^{2}$ & $4 \times 10$ & ND & $3.0 \times 10$ & ND \\
\hline$(1.5 \%)$ Rosemary & $3 \times 10^{2}$ & $3 \times 10$ & ND & $3.5 \times 10$ & ND \\
\hline (2.5\%) Rosemary & $1 \times 10^{2}$ & $1.5 \times 10^{2}$ & ND & $2.0 \times 10$ & ND \\
\hline \multicolumn{6}{|c|}{ Count in fried samples } \\
\hline Control & $5 \times 10^{2}$ & $5 \times 10^{2}$ & ND & ND & ND \\
\hline (1\%) Sumac & $6 \times 10$ & $1.2 \times 10^{2}$ & ND & ND & ND \\
\hline (1.5\%) Sumac & $5 \times 10$ & $9 \times 10$ & ND & ND & ND \\
\hline (2\%) Sumac & $1 \times 10$ & ND & ND & ND & ND \\
\hline$(1 \%)$ Rosemary & $6 \times 10$ & $9 \times 10$ & ND & ND & ND \\
\hline$(1.5 \%)$ Rosemary & $3 \times 10$ & $7 \times 10$ & ND & ND & ND \\
\hline (2.5\%) Rosemary & $1 \times 10$ & ND & ND & ND & ND \\
\hline
\end{tabular}




\section{CONCLUSION}

The sumac and rosemary showed a remarkable inhibitory activity against the growth of food spoilage and/or poisoning bacteria, especially Salmonella and Staph. aureus. On the other hand, sumac fruit powder exhibited a good antioxidative capacity. Therefore, the sumac fruit and rosemary leaves can be used as a natural source of antimicrobial and antioxidant agents to preserve foodstuffs against a range of food related microorganisms. The sumac and rosemary species can be considered as good sources of additives and/or ingredients for the food industry. These findings would be useful for food scientists and nutritionists interested in the nutritive value of nonconventional plants such as sumac and rosemary. Results of this study showed that the fruit of the sumac are, also, a good source of phenolic compounds, which are strong antioxidants.

\section{REFERENCES}

1. A.M.S.A. 1995. Research guidelines for cookery, sensory evaluation and instrumental tenderness measurements of fresh meat. American Meat Science Association and National Livestock and Meat Board, Chicago, IL;p 475.

2. AOAC. 2000. Association of Official Analytical Chemists. Official Methods of Analyses, $17^{\text {th }}$ ed. Gaithersburg. M.D.

3. A.P.H.A. 2004. Standard Methods for the Examination of Dairy Products. $17^{\text {th }}$ Ed., American Public Health Association Inc., New York. p 570.

4. Asia, B.; Subarda,S.,;Syed, Ali, K.; Ravindran, V.; Swapna, R.and David, B. 2013. An in-depth review on the medicinal flora Rosmarinus officinalis (lamiaceae). Acta Sci. Pol. Technol. Aliment., 12(1): 61-73.

5. Chung, K. T., T. Y. Wong, C. I. Wei, Y. W. Huang, and Y. Lin. 1998. Tannins and human health: A review. Crit. Rev. Food Sci. Nutr. 38:421-464

6. Cofrades, S.; Guerra, M. A.; Carballo, J.; Fernandez-Martin, F. and JimenezColmenero, F. 2000. Plasma protein and soy fiber content effect on bologna sausage properties as influenced by fat level. J Food Sci, 65: 281-287.

7. Difco. 1994. DIFCO Manual of Dehydrated Culture Media and Reagents for Microbiological and Clinical Laboratory Procedure. $10^{\text {th }}$ Ed., DIFCO Lab. Inc. Detroit I., Michigan, USA 
8. Farrell, k. T. 1999. Spices, condiments and seasoning .In: Spices and Spices Blend, second edition. An AVI Book, published by Van Nostrand Reinhold, New York.414 pp.

9. Guntersperger, B., Hammerli-Meier-, D.E. and Escher, F.E. 1998. Rosemary extract and precooking effects on lipid oxidation in heat sterilized meat. J. Food Sci. $63,95$.

10. Kossah, R.; Nsabimana,C.; Zhang,H. and Chen,W. 2013. Evaluation of antimicrobial and antioxidant activities of Syrian sumac fruit extract. Journal of Natural Products, 6: 96-102.

11. LIU, J.; WANG, S. 2005. Antioxidant Activities of Blackberry Pigment Extract. Food Technology and Biotechnology, Zhengzhou, 43(1): 97-102.

12. Mata, A. T. 2007). Antioxidant and antiacetylcholinesterase activities of five plants used as Portuguese food spices. Food Chemistry, Lisbon, 103 (3):778-786.

13. Mattick, K. L.; Phillips, L. E.; Jrgensen, F.Lappin-Scott, H. M. and Humphrey, T. J. 2003. Filament formation by Salmonella spp. inoculated into liquid food matrices at refrigeration temperatures, and growth patterns when warmed. Journal of Food Protection, 66: 215-219..

14. Mrema, N.; Mquchane, S. and Gash, B. A. 2006. Prevalence of Salmonella in raw minced meat, raw fresh sausages and raw burger patties from retail outlets in Gaborone,Botswana. Food Control, 17: 207-212.

15. Musa, Ö. 2003. Antioxidant Activities of Rosemary, Sage, and Sumac. Extracts and Their Combinations on Stability of Natural Peanut Oil. J.Med. Food. 6(3): 267-270.

16. Nychas, G. - J. E.; Skandamis, P. N.; Tassou, C. C. and Koutsoumanis, K. P. 2008. Meat spoilage during distribution. Meat Science, 78: 77-89.

17. Oiye, S.O and Muroki, N.M. 2002. Use of Spices in Foods. Journal of food Technology in Africa 7: 39-44.

18. Omojola, A. B. 2008. Yield and organoleptic characteristics of suya (an intermediate moisture meat) prepared from three different muscles of a matured bull. African Journal of Biotechnology, 7: 22542257.

19. Özcan, M. and Haciseferogullari, H. 2004. A condiment [sumac (Rhus coriaria L.) fruits]: Some physicochemical properties. Bulg. J. Plant Physiol., 30: 74- 84.

20. Rajalakshmi,I, D. and Narasimhan, N, S. 1996. Food antioxidants: Sources and methods of evaluation. In Food Antioxidants (D.L. Madhavi, S.S. Deshpande and D.K. Salunkhe, eds.) p. 5, Marcel Dekker, NewYork. 
21. Rhee, K.S. 1988. Enzymic and nonenzymic catalysis of lipid oxidation in muscle foods. Food Technol. 42, 127.

22. SAS. 1987. Statistical Analysis System. Release 6.03. SAS Institute.Inc. Carry, NC, USA.

23. Whyte, P.; Mcgill, K. and Collins, J. D. 2003. An assessment of steam pasteurization and hot water immersion treatments for the microbiological decontamination of broiler carcasses. Food Microbiology, 20: 111-117.

24. Singleton, V.L. and Rossi, J.A. 1965. Colorimetry of total phenolic with phosphomolybdic-phosphotungstic acid reagent. Am. J. Enol. Viticult., 16: 144158.

25. Yang, B.; Zhao, M. M.; Shi, J.; Yang, N. and Jiang, Y. M. 2008. Effect of ultrasonic treatment on the recovery and DPPH radical scavenging activity of polysaccharides from longan fruit pericarp. Food Chem., 106: 685-690. 


\title{
دراسة مقارنة لاستخدام السماق و الروز مارى فى حفظ الكفتة اثناء التخزين
}

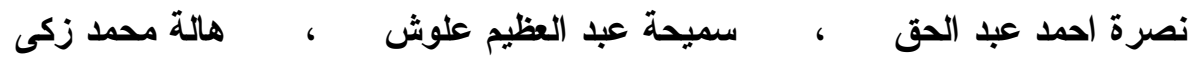

$$
\text { معهُ بحوث تكنولوجيا الاغذية - مركز البحوث الزراعية - جيزة }
$$

لوحظ فى الاونة الاخيرة ازدياد الاهتمام باستخدام المواد النباتية وخاصة التوابل (السماق

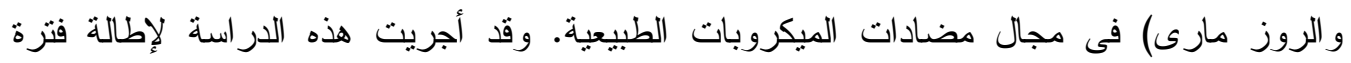

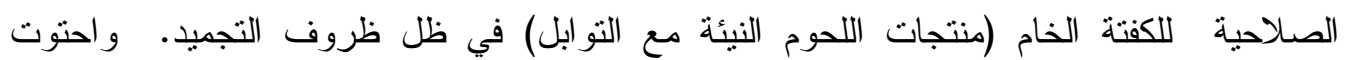

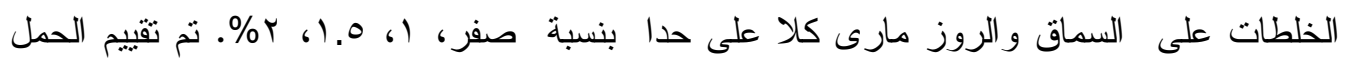

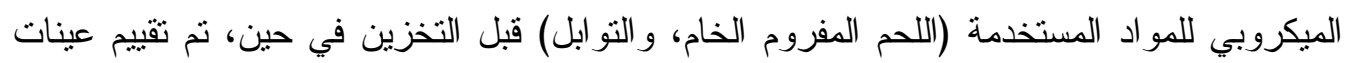

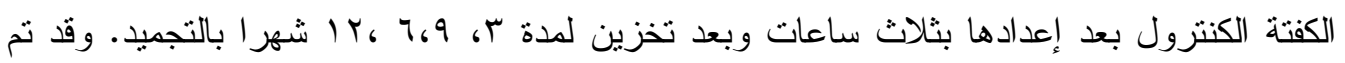

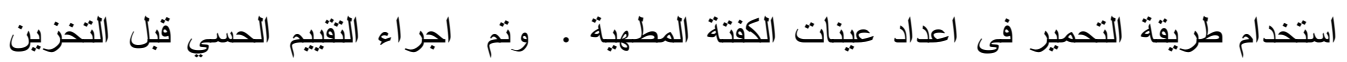
وقد أظهرت النتائج ان القبول الحسى الافضل كان عند استخدام r\% من السماق. و أنثارت النتائج

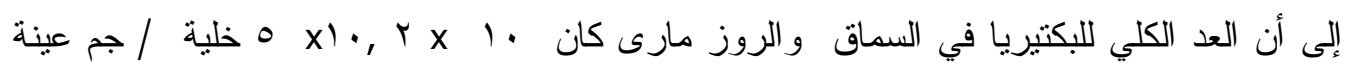

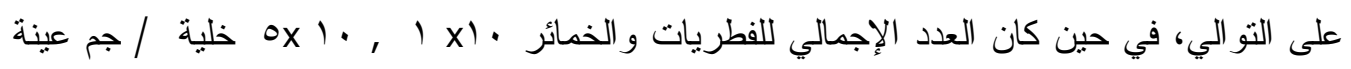

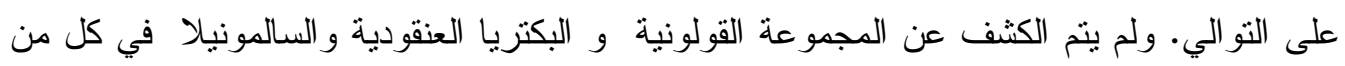

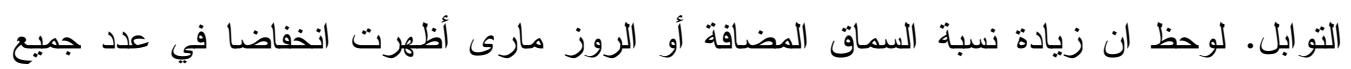

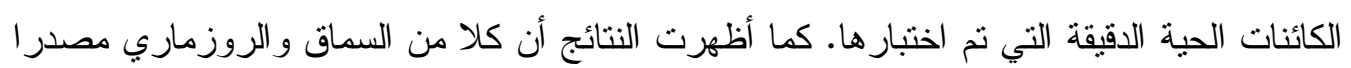

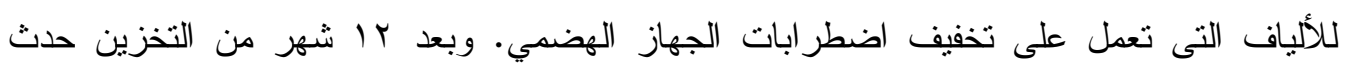

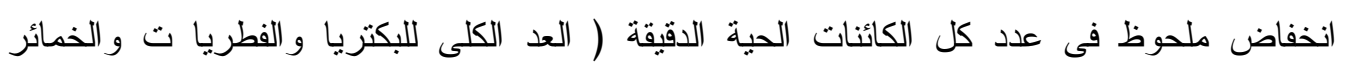

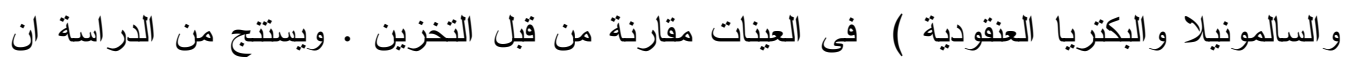
ثمار السماق يمكن ان تكون مصدر جيد من المركبات الفينولية، المواد المضادة للاكسدة .

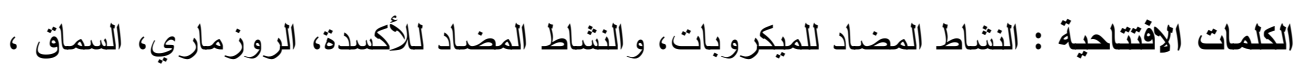

$$
\text { اختبار ات ميكروبيولوجية. }
$$

